\title{
Study of general technical disciplines via interactive audiovisual tools in conditions of informational and educational environment
}

\author{
Dotsenko N.* \\ Mykolayiv National Agrarian University, Mykolayiv, Ukraine
}

Received: $15.03 .2019 \quad$ Accepted: 16.04 .2019

\begin{abstract}
The study of general technical disciplines for the future engineers training of requires the use of interactive audiovisual tools. Such tools can offer an informational and educational environment. The use of interactive audiovisual tools enhances the quality of theoretical and practical provisions of general technical disciplines. To prepare applicants of higher education in engineering specialties it is expedient to form modern electronic interactive manuals for on disciplines studying in the conditions of the informational and educational environment. Such resources are assistance in mastering both theoretical material and course navigation, which provides interactive electronic learning tools for performing tasks in an informational and educational environment. The tasks for higher education applicants are performed directly in the audience using gadgets or personal computers. The final score is formed from the points obtained in the audience and the rating of higher education applicants during the study in the informational and educational environment. It is expedient to provide information in the informational and educational environment with the help of QR-codes in the methodical literature for studying in the informational and educational environment. General technical disciplines require the mastering of theoretical knowledge, reinforcement by their practical calculations and testing them experimentally. Theoretical positions of general technical disciplines are expedient to learn through lectures with audiovisual accompaniment. Practical tasks are performed on the basis of multimedia materials for practical work, and simplification and automation in performing calculations can be done using online calculators, modeling and design tools. The experimental part in the study of general technical disciplines must be supported by video clips and the implementation of interactive laboratory work. The outlined approach can help in qualitative mastering of educational content in the chosen specialty and reinforcement of engineering skills of higher education applicants.
\end{abstract}

Key words: engineering training, educational environment, audiovisual content, mobile learning, information and communication facilities.

\section{Вивчення загальнотехнічних дисциплін в умовах інформаційно- освітнього середовища за допомогою інтерактивних аудіовізуальних засобів Доценко Н. А.}

Миколаївський національний аграрний університет, Миколаїв, Україна

\begin{abstract}
Анотація. Вивчення загальнотехнічних дисциплін при підготовці майбутніх інженерів потребує використання інтерактивних аудіовізуальних засобів. Такі засоби може запропонувати інформаційно-освітнє середовище. Використання інтерактивних аудіовізуальних засобів підвищує якість засвоєння теоретичних і практичних положень загальнотехнічних дисциплін. Для підготовки здобувачів вищої освіти інженерних спеціальностей доцільно формувати сучасні електронні інтерактивні посібники по дисциплінам для вивчення кожної в умовах інформаційно-освітнього середовища. Такі посібники є допомогою в опануванні як теоретичного матеріалу, так і навігацією по курсу, де представлені інтерактивні електронні навчальні інструменти для виконання завдань в умовах інформаційно-освітнього середовища. Такі завдання здобувачі вищої освіти виконують прямо в аудиторії за допомогою гаджетів або персональних комп'ютерів. Підсумкова оцінка формується 3 балів, отриманих в аудиторії та рейтингу здобувачів вищої освіти під час навчання в умовах інфрормаційноосвітнього середовища. Подавати інформацію в умовах інформаційно-освітнього середовища доцільно за
\end{abstract}

\footnotetext{
Corresponding Author: Dotsenko Nataliia. Tel. +38(095)174-84-74. E-mail: dotsenkona@outlook.com Mykolayiv National Agrarian University, vul. Heorhiia Honhadze, 9, m. Mykolaiv, Ukraina, 54020.

Відповідальний автор: Доценко Наталія Андріївна. +38(095)174-84-74. E-mail: dotsenkona@outlook.com Миколаївський національний аграрний університет, вул. Георгія Гонгадзе, 9, м. Миколаїв, Україна, 54020.
} 
допомогою QR-кодів в методичній літературі для навчання в умовах інформаційно-освітнього середовища. Загальнотехнічні дисципліни потребують засвоєння теоретичних знань, підкріплення їх практичними розрахунками та перевірки їх експериментальним шляхом. Теоретичні положення загальнотехнічних дисциплін доцільно опановувати за допомогою лекцій з аудіовізуальним супроводом. Практичні завдання виконуються на основі мультимедійних матеріалів до практичних робіт, а спрощення та автоматизацію у виконанні розрахунків можна виконувати за допомогою онлайн-калькуляторів, засобів моделювання та проектування. Експериментальну частину при вивченні загальнотехнічних дисциплін необхідно підкріплювати відеороликами та виконанням інтерактивних лабораторних робіт. Окреслений підхід здатен допомогти в якісному опануванні навчального контенту за обраним фахом та підкріпленню інженерних навичок здобувачів вищої освіти.

Ключові слова: інженерна підготовка, навчальне середовище, аудіовізуальний контент, мобільне навчання, інформаційно-комунікаційні засоби.

\title{
Изучение общетехнических дисциплин в условиях информационно- образовательной среды с помощью интерактивных аудиовизуальных средств
}

\author{
Доценко Н. А. \\ Николаевский национальный аграрный университет, Николаев, Украина
}

\begin{abstract}
Аннотация. Изучение общетехнических дисциплин при подготовке будущих инженеров требует использования интерактивных аудиовизуальных средств. Такие средства может предложить информационно-образовательная среда. Использование интерактивных аудиовизуальных средств повышает качество усвоения теоретических и практических положений общетехнических дисциплин. Для подготовки соискателей высшего образования инженерных специальностей целесообразно формировать современные электронные интерактивные пособия по дисциплинам для изучения каждой в условиях информационнообразовательной среды. Такие пособия является помощью в овладении как теоретическим материалом, так и навигацией по курсу, где представлены интерактивные электронные учебные инструменты для выполнения задач в условиях информационно-образовательной среды. Такие задачи соискатели высшего образования выполняют прямо в аудитории с помощью гаджетов или персональных компьютеров. Итоговая оценка формируется из баллов, полученных в аудитории и рейтинга соискателей высшего образования во время обучения в условиях информационно-образовательной среды. Подавать информацию в условиях информационно-образовательной среды целесообразно с помощью QR-кодов в методической литературе для обучения в условиях информационно-образовательной среды. Общетехнические дисциплины требуют усвоения теоретических знаний, подкрепления их практическими расчетами и проверки их экспериментальным путем. Теоретические положения общетехнических дисциплин целесообразно осваивать с помощью лекций с аудиовизуальным сопровождением. Практические задания выполняются на основе мультимедийных материалов к практическим работам, а упрощение и автоматизацию в выполнении расчетов можно выполнять с помощью онлайн-калькуляторов, средств моделирования и проектирования. Экспериментальную часть при изучении общетехнических дисциплин необходимо подкреплять видеороликами и выполнением интерактивных лабораторных работ. Очерченный подход способен помочь в качественном освоении учебного контента по выбранной специальности и подкреплению инженерных навыков соискателей высшего образования.
\end{abstract}

Ключевые слова: инженерная подготовка, учебная среда, аудиовизуальный контент, мобильное обучение, информационно-коммуникационные средства.

\section{Bcmyn}

Задоволення нових запитів суспільства в підготовці інженера вимагає перебудови всієї роботи сучасного закладу вищої освіти. Найважливіші вимоги, які пред'являє до системи освіти сучасність, глобалізація і інтернаціоналізація, стандартизація та уніфрікація, відкритість і доступність, висока якість освітніх послуг, що забезпечують конвертованість освіти, соціальну та професійну мобільність майбутнього інженера, його конкурентоспроможність та навчання за допомогою інноваційних технологій. Інноваційні технології - це ті, які передбачають не стільки освоєння дисципліни, скільки формування компетенцій, для чого використовують активні та інтерактивні методи навчання. До таких технологій належать, наприклад, інформаційно-комунікаційні технології (залучення комп'ютеризації у вивченні технічних дисциплін), особистісно-орієнтовані технології (розвиваючі природні дані учнів, 
комунікативні здібності), дидактичні (використання нових прийомів, методів в навчальному процесі) та iн.

При підготовці сучасних інженерів виникає необхідність перетворення системи підготовки, постає потреба в нових підходах, які пов'язані з міждисциплінарністю навчання та використанням сучасних інтерактивних технологій. Такий рівень підготовки здобувачів вищої освіти інженерних спеціальностей забезпечується в умовах інформаційно-освітнього середовища. Одним із інтерактивних аудіовізуальних засобів інформаційно-освітнього середовища $є$ мобільні додатки. У міру зміни освітніх практик та технологічних інструментів, навчання з використанням мобільно-планшетних технологій, продовжує розвиватися. У 2018 році акцент робиться на різних аспектах, починаючи від того, як здобувачі вищої освіти отримують доступ до змісту, як визначається ідея «навчального плану». Технології, такі як планшети, мобільні телефони, персональні комп'ютери, програми та доступ до Інтернету, полегшують перехід до мобільного навчання, але занурення в мобільне навчальне середовище виходить за рамки інструментів для навчання [1, 2].

Багаторічний досвід щодо розроблення й теоретичного обґрунтування електронних освітніх ресурсів був узагальнений у працях В. Ю. Бикова [3]. Теоретичні основи застосування інформаційнокомунікаційних теххнологій у процесі навчання досліджувались у роботах Ю. С. Рамського [4], С. О. Семерікова [5], Ю. В. Триуса [6] та інших дослідників.. Теорія та методики використання інформаційнокомунікаційних технологій у навчанні фрізико-математичним дисциплінам розроблялись у роботах В. І. Клочка [7], О. В. Співаковського [8] та інших. Вакалюк Т. А. [9] вивчав хмарно орієнтовані засоби навчання. Опису моделювання і проектування освітнього середовища закладів вищої освіти присвячені роботи А.М. Гуржій, М.П. Шишкіної [10]. У працях О. М. Самойленка, І. В. Бацуровської [11] визначались засоби модернізації освітніх технологій в умовах інформаційно-освітнього середовища. Методики створення та використання інформаційно-комунікаційних технологій в інформаційному освітньому середовищі закладу вищої освіти розроблені за участю О.Г. Глазунової [12], Н.В. Морзе [13], Е. Smyrnova-Trybulska [14]. Наукові дослідження, присвячені проблемі вивчення та викладання загальнотехнічних дисциплін, досліджував Авраменко О. Б. В працях науковця відзначається необхідність встановлення і розвитку міжпредметних зв'язків і взаємодій, до реалізації політехнічного принципу викладання, до відображення об'єктивно існуючих зв'язків науки і виробництва, тобто науки, техніки і технології [15]. Але недостатню увагу було приділено вивченню загально технічних дисциплін як базової підготовки здобувачів вищої освіти інженерних спеціальностей в умовах інформаційноосвітнього середовища за допомогою інтерактивних аудіовізуальних засобів.

В ході нашого дослідження можливо висунути декілька гіпотез. По-перше, використання комп'ютерно-планшетних додатків та інтерактивних аудіовізуальних засобів підвищить якість виконання робіт. По-друге, використання лекцій з аудіовізуальним супроводом дасть змоу підвищити якість засвоєння матеріалу. По-третє, використання онлайн-калькуляторів та засобів моделювання та проектування дасть змогу збільшити кількість часу для вирішення і опрацювання різних типів задач, не витрачаючи час на розрахунки.

Meта роботи: охарактеризувати інтерактивні аудіовізуальні засоби для вивчення загальнотехнічних дисциплін в умовах інформаційно-освітнього середовища.

\section{II Матеріал і методи дослідження}

у процесі розробки системи інтерактивних аудіовізуальних засобів для вивчення загальнотехнічних дисциплін, спрямованих на забезпечення якості підготовки майбутніх інженерів у закладах вищої освіти, нами було проаналізовано використання цих засобів в умовах інформаційноосвітнього середовища та ефективність підготовки майбутніх фахівців за умови користування цими інструментами. Використовувались такі методи дослідження: опитування та анкетування здобувачів вищої освіти та моніторинг їх оцінок в умовах інформаційно-освітнього середовища.

Вивчення загальнотехнічних дисциплін в умовах інсрормаційно-освітнього середовища за допомогою мобільно-планшетних пристроїв підтримує постійний доступ до процесу навчання. Це може бути на таких пристроях, як телефон, ноутбук або планшет. 3 появою мобільного навчання, освітні системи змінюються. Можна запропонувати тексти, відео чи аудіо. Здобувачі вищої освіти мають можливість підготувати домашнє завдання, переглянувши відео, яке викладач поставив онлайн. Варіант 
з більшим ступенем взаємодії можливий, коли використовуються мобільні пристрої під час занять. Зокрема $є$ можливість отримати прямий зворотний зв'язок під час навчання вдома. Також викладачі можуть взаємодіяти із здобувачами вищої освіти під час лекцій [16].

Існує велика кількість допоміжного контенту, який може покращити освітній процес, але він не завжди використовується. Для успішного використання цього контенту необхідний куратор, який на основі спеціалізованих знань, об'єднує відповідні навчальні засоби та шляхи для здобувачів вищої освіти. Важливим заходом у розвитку мобільного навчання $€$ надання здобувачам вищої освіти можливості внести свій внесок та збагатити програму куратора. Використання аудіовізуальних матеріалів збільшується в геометричній прогресії під час навчання. Інтерактивне навчання на основі відеоролика пропонує набагато вищий рівень залученості та досвіду навчання, а також зростає рівень як формального, так і нефрормального навчання. Для створення навчального контенту зручними $\epsilon$ мобільні додатки, оскільки вони оптимізовані для мобільних пристроїв. Вони пропонують додаткову гнучкість навчання, оскільки здобувачі вищої освіти можуть завантажувати навчальний контент і переглядати його в автономному режимі. Використання гейміфікації для навчання $€$ зручним 3 розширенням перегляду навчального контенту на мобільних пристроях. Навчання з використанням мобільно-планшетних засобів надає можливість доступу до освітнього контенту, в умовах інфрормаційно-освітнього середовища можна забезпечити роботу колег, експертів, ознайомитись 3 достовірними джерелами для опрацювання відповідних тем. Воно може бути активоване за допомогою смартфона або планшета, ноутбука або особистого комп'ютера, але доступ є постійним, що, у свою чергу, перекладає навантаження для вивчення на здобувача вищої освіти. Мобільне навчання розширює доступ до різноманітних інструментів для подачі навчального контенту [17, 18]. Хмарні технології є засобом забезпечення мобільності. Маючи доступ до хмари, для здобувачів вищої освіти всі джерела даних та навчальні матеріали є постійно доступні, що дозволяє досягати раніше недоступних рівнів навчання та співпраці. Прозорість $є$ продуктом підключення, мобільності та співпраці. Оскільки планування, мислення, продуктивність та відображення є мобільними та цифровими, вони отримують безпосередню аудиторію як з місцевих, так і з глобальних спільнот через платформи соціальних мереж. Для вивчення загальнотехнічних дисциплін в умовах інформаційно-освітнього середовища (рис. 1).

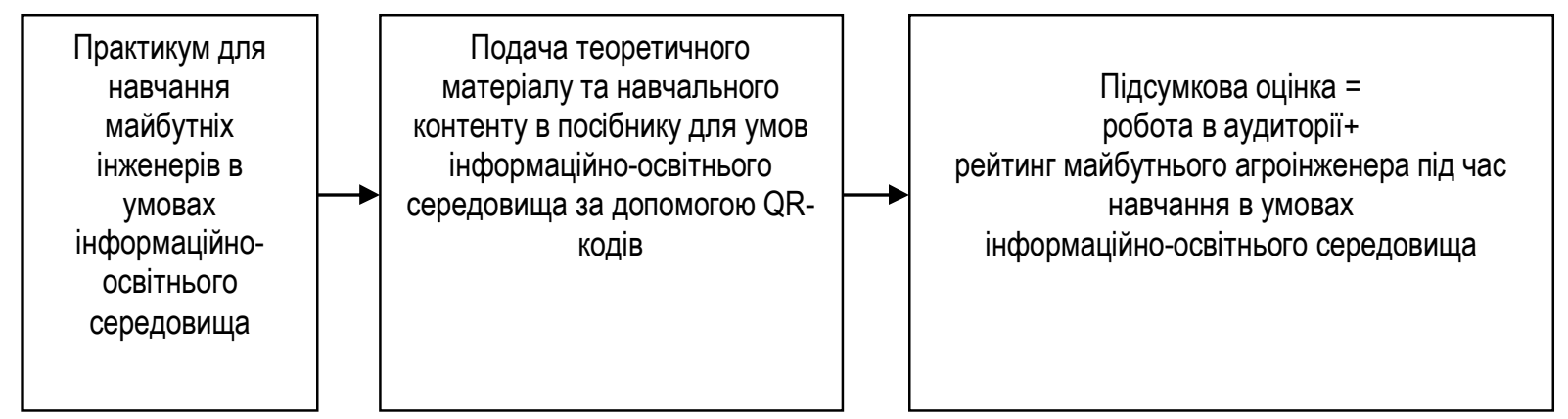

Рис.1. Схема вивчення загальнотехнічних дисциплін в умовах інформаційно-освітнього середовища навчання з використанням мобільно-планшетних засобів

Схема вивчення загальнотехнічних дисциплін в умовах інформаційно-освітнього середовища за допомогою практикумів для навчання в умовах інформаційно-освітнього середовища здійснюється наступним чином: здобувачі вищої освіти ознайомлюються попередньо з теоретичним матеріалом. Потім в аудиторії вони починають практичне виконання завдань, які представлені в навчальному посібнику за допомогою QR-кодів. Здобувачі вищої освіти, за допомогою додатків для зчитування QRкодів переходять на відповідний розділ курсу та приступають до виконання завдань на мобільному телефоні, що представлені за допомогою інтерактивних електронних інструментів, а саме: мультимедійні презентації до практичних робіт, інтерактивні лабораторні роботи, лекції 3 аудіовізуальним супроводом, інтерактивні комп'ютерні навчальні тренажери тощо. Виконавши 3 мобільного телефону завдання, інформаційно-освітнє середовище формує оцінку для здобувачів вищої освіти та статистичні показники щодо виконання завдання для викладача. Таким чином, для майбутніх 
інженерів формується рейтинг під час навчання в умовах інформаційно-освітнього середовища, який впливає на підсумкову оцінку.

Тобто, для того, щоб опанувати аспекти загальнотехнічних дисциплін необхідно окрім засвоєння теоретичних знань, підкріплення їх практичними розрахунками та перевірки їх експериментальним шляхом. Опанування такої великої кількості матеріалу здійснюється за наступною схемою (рис. 2).

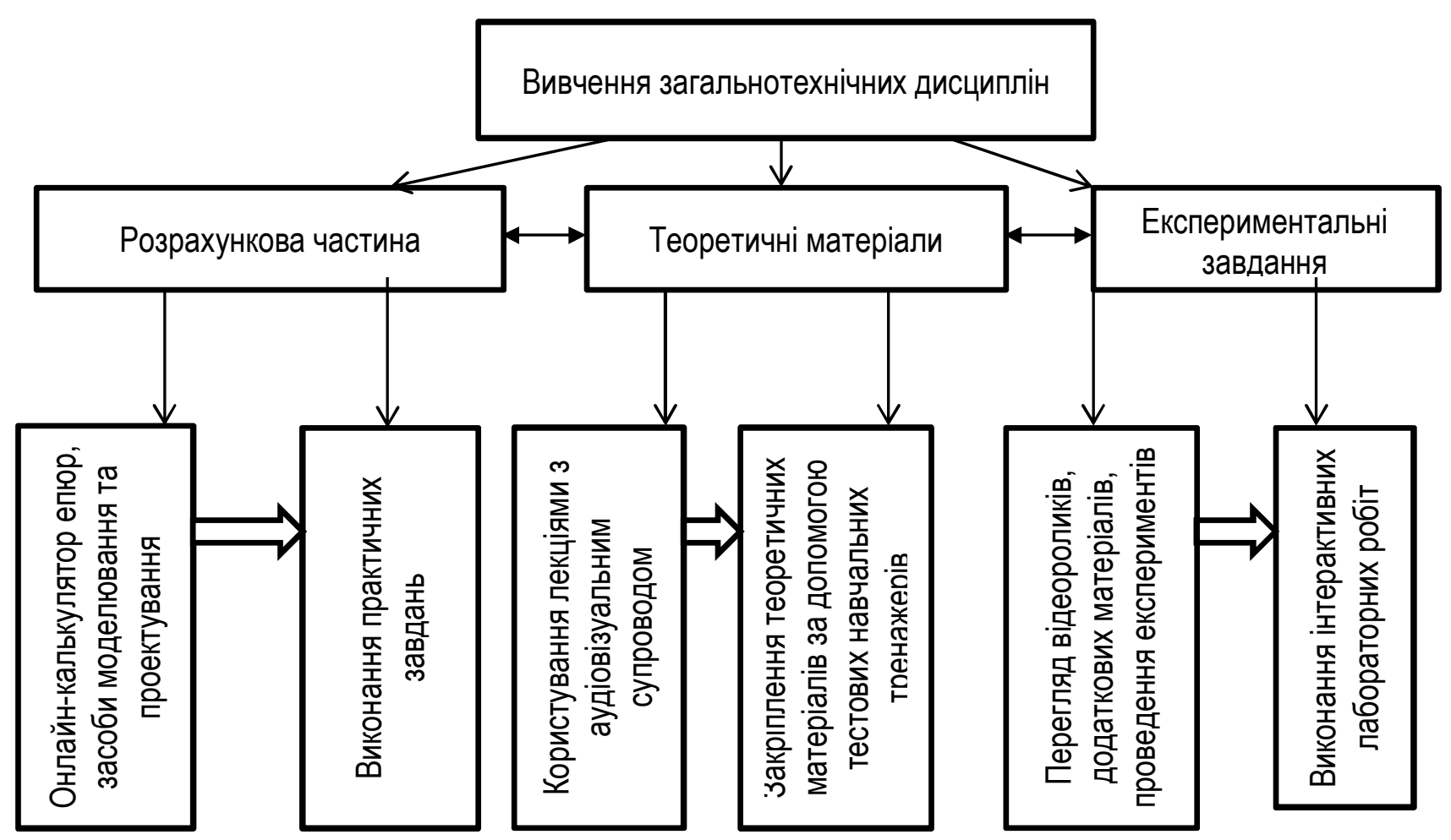

Рис. 2. Схема вивчення загальнотехнічних дисциплін в умовах інформаційно-освітнього середовища

\section{III Результати}

Вивчення загальнотехнічних дисциплін в умовах інформаційно-освітнього середовища за схемою, представленою на рис.2 потребує використання інтерактивних аудіовізуальних засобів. Вони можуть подаватись в методичній літературі з дисципліни за допомогою QR кодів. Загальний вигляд курсу та представлення завдань в методичній літературі показані на рис.3. Наприклад, навчальний курс 3 дисципліни «Механіка матеріалів і конструкцій» вміщує в себе: лекції з аудіовізуальним супроводом, інтерактивні комп'ютерні навчальні тренажери, мультимедійні презентації до практичних робіт, інтерактивні лабораторні роботи. Кожна лекція доповнюється інтерактивним контентом, інтерактивні лабораторні роботи супроводжуються $Q R$ кодом на інтерактивний аудіовізуальний контент. Самостійна робота з модуля може вміщувати перелік рекомендованої літератури, посилання на візуальний контент тощо.

Наприклад, в курсах механіки матеріалів і конструкцій, прикладної та інженерної механіки необхідно: побудувати епюру; підібрати поперечний переріз та розміри; визначити деформацію поперечних перерізів. Для вивчення теоретичної частини цього питання передивляємося лекцію 3 аудіовізуальним супроводом та проходимо тестовий навчальний тренажер (рис. 4).

Для виконання експериментальної частини роботи використовується відео контент за допомогою якого виконуються інтерактивні лабораторні роботи (рис. 5). 




Рис. 3. Загальний вигляд курсу з дисципліни «Механіка матеріалів і конструкцій» та використання QRкодів для подачі аудіовізуального контенту


Рис. 4. Лекція з аудіовізуальним супроводом та тестовий навчальний тренажер до неї

Для практичного розрахунку лабораторної роботи з дисципліни «Механіка матеріалів і конструкцій» на тему «Центральний розтяг-стиск» використовуємо мультимедійну презентацію та онлайн-калькулятор епюр (рис. 6). Для користування ним необхідно ввести вихідні дані. Для отримання розрахунку натискаємо «Отримати розв'язок» отримуємо докладний розв'язок, а також епюри. 


\section{Лабораторна робота 1. Випробування зразка на розтяг}
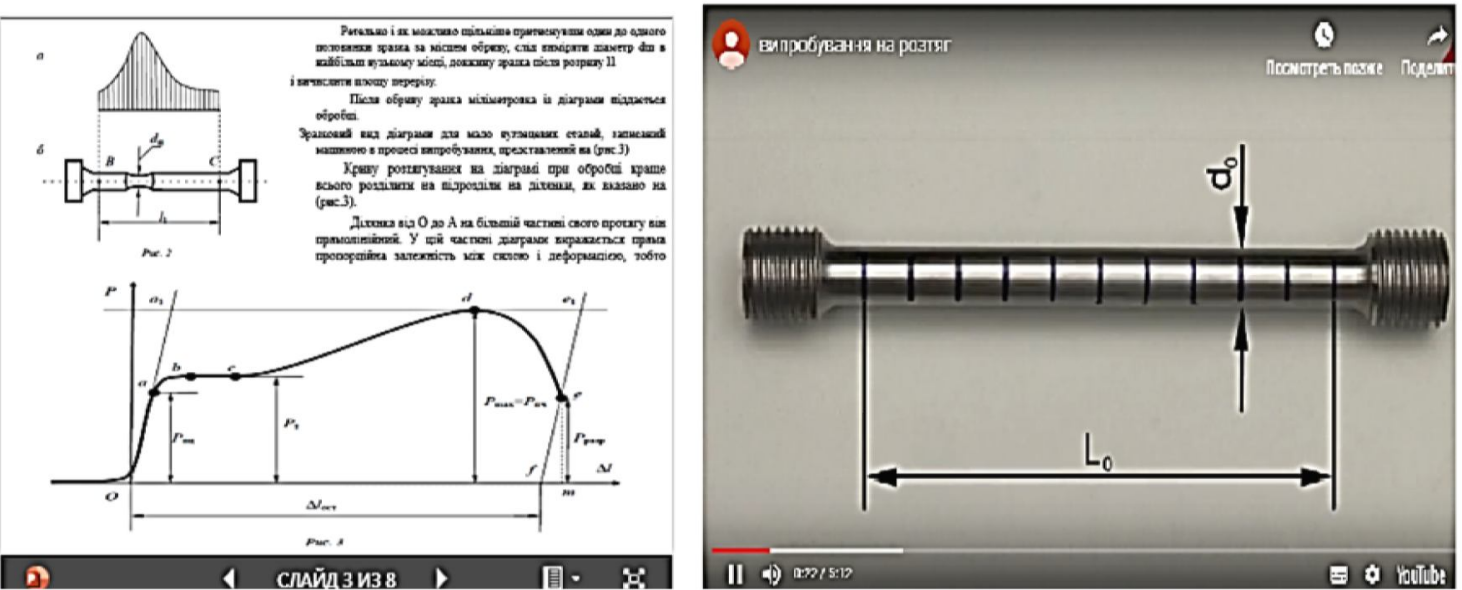

Рис. 5. Інтерактивна лабораторна робота з дисципліни «Механіка матеріалів і конструкцій» на тему «Механічні властивості матеріалів» та відео інструкція щодо їі виконання
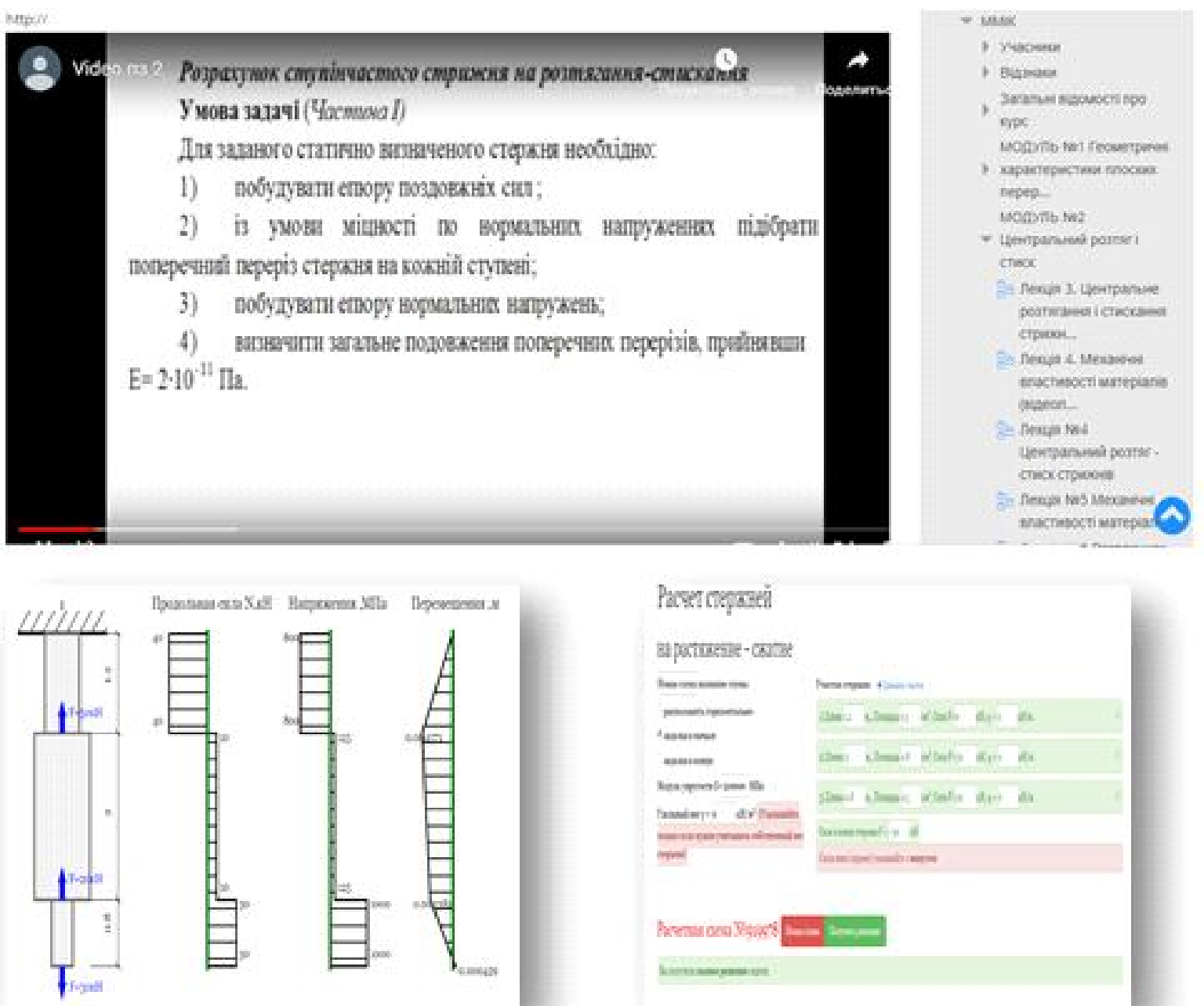

Pacer topasati

apotimente-cosat
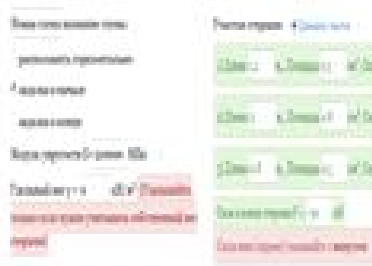

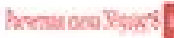

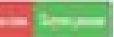

Lenens.

Рис. 6. Виконання практичної роботи з дисципліни «Механіка матеріалів і конструкцій» на тему «Центральний розтяг-стиск» за допомогою мультимедійної презентації та онлайн-калькулятора епюр 
Результативність використання інтерактивних аудіовізуальних засобів при вивченні загальнотехнічних дисциплін здобувачами вищої освіти інженерних спеціальностей в умовах інформаційно-освітнього середовища підтверджується моніторинговими даними перевірки якості знань та набуття фрахових компетентностей. На рис.7 показано діапазон оцінок здобувачів вищої освіти спеціальності «Агроінженерія» при вивченні дисципліни «Механіка матеріалів і конструкцій». По осі абсцис показана кількість учасників, що отримали оцінку, по осі ординати - діапазон балів за завдання (від 1 до 10).

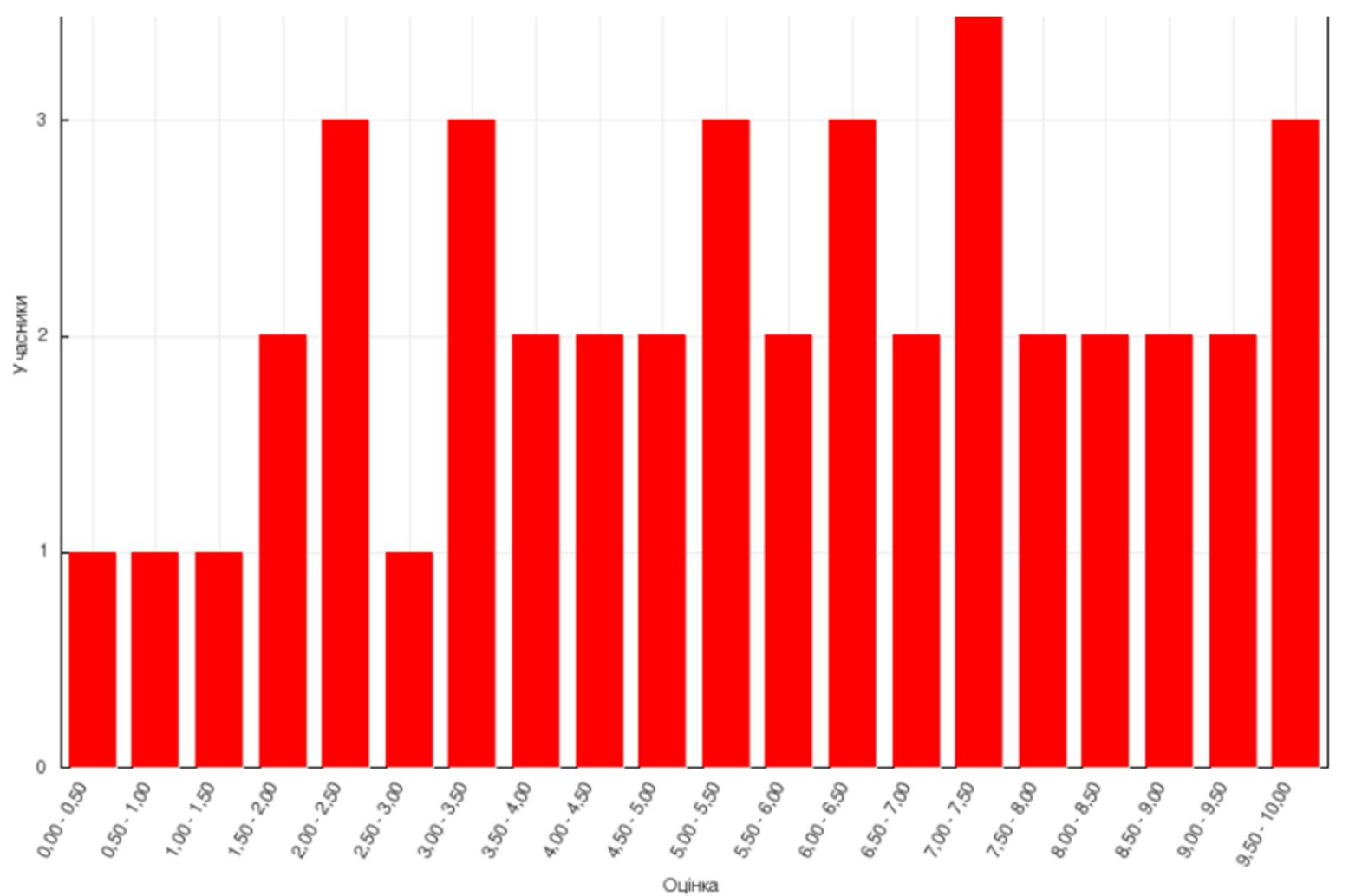

Рис. 7. Діапазон оцінок здобувачів вищої освіти спеціальності «Агроінженерія» при вивченні дисципліни «Механіка матеріалів і конструкцій»

\section{IV Обговорення}

Відкритий доступ до інформаційних технологій підвищує продуктивність і конкурентоспроможність будь-якого фахівця і вимагає значних змін у системі освіти. Один з найбільш інноваційних підходів в освіті - це гейміфікація навчання, яка має значні можливості для підвищення зацікавленості здобувачів вищої освіти [24]. Вивчення професійної підготовки майбутніх фахівців з інженерних спеціальностей за допомогою розвитку системи навчально-методичних комплексів забезпечують процес інтелектуальної мобільності в освітньому середовищі сучасного технічного університету [25]. Підвищення мотивації здобувачів вищої освіти до навчання стримується обмеженим досвідом упровадження анімованих графрічних матеріалів. Авторами описана схема створення анімації моделі технічного об'єкта і їі сприйняття в контексті підвищення мотивації [26]. Створені комп'ютерно-орієнтовані засоби враховують наявність послідовних модулів, що забезпечують багатофункціональність запропонованого навчального комплекту. Виокремлені модулі узгоджені з видами навчальної діяльності здобувача вищої освіти та сприяють цілеспрямованому управлінню дослідницькою роботою у ході фізичного практикуму і $\epsilon$ важливим чинником в організації й керуванні самостійною роботою здобувача вищої освіти [27]. Детальніше процеси інтеграції, що стосуються загальнотехнічних дисциплін досліджувались в роботі В. Курка [28]. Ми погоджуємося з його твердженням, що: оптимальна підготовка фрахівців відповідно до сучасних потреб та вимог суспільства, підвищення мобільності випускника в період його професійної 
діяльності, забезпечення дидактичної ефективності процесу навчання (усунення дублювання інформації в навчанні і, зменшення загальної кількості навчальних дисциплін та форм контролю знань) зумовлює інтеграцію споріднених дисциплін.

При вивченні загальнотехнічних дисциплін дуже важливим $€$ дотримання компетентнісного підходу, але зважаючи на сучасні методики викладання. Кожне завдання може бути представлено у вигляді діаграми [19], що показує фрактори та ступінь їх вплив на успішне виконання завдання. Застосування хмарних освітніх навчальних сервісів забезпечує індивідуальний підхід до навчання [20]. Здобувачі вищої освіти можуть використовувати мультимедійні технології при виконанні творчих проектів [21]. В умовах інформаційно-освітнього середовища доцільним було б проведення відео конференції для обговорення проблемних питань при вивченні технічних дисциплін зі здобувачами вищої освіти із залученням експертів-практиків.

Відеоуроки дають змогу внести новизну в класичний навчальний процес і автоматизувати його та перерозподілити навчальний час на користь позааудиторної самостійної роботи і вивільнити лекційний час для більш повного викладу фундаментальних основ навчальних дисциплін. Здобувачі вищої освіти можуть переглядати короткі відеоуроки багаторазово з різних пристроїв, зокрема мобільних, вдома чи під час аудиторних занять [22]. Але при вивченні загальнотехнічних дисциплін в умовах інформаційноосвітнього середовища, доцільно було б теоретичний матеріал закріпити за допомогою проходження інтерактивних комп'ютерних навчальних тренажерів. Використання платформи дистанційного навчання Moodle дає можливість викладачу зекономити час на перевірку завдань, а також забезпечує усім учасникам освітнього процесу вільний доступ до обговорення його розв'язання [23]. Практичні заняття закріплюються мультимедійними презентаціями до їх виконання, також можна підкріплювати отримані навички за допомогою засобів моделювання та проектування та онлайн-калькуляторів. Застосування комп'ютерних інтерактивних тренажерів та віртуальних лабораторій вивчалося [1, 2], але для підготовки здобувачів вищої освіти інженерних спеціальностей недостатньо використовувати лише навчальні тренажери, тут необхідно поєднувати всі складові частини курсу в єдиному середовищі.

В нашому дослідженні підтверджуються гіпотези про те, що:

- важливо враховувати теоретичну, практичну та експериментальну складові та підтримувати їх за допомогою завдань, що можна виконувати в умовах інформаційно-освітнього середовища;

- необхідно враховувати фахову специфіку, адже навчання здобувачів вищої освіти загально технічним дисциплінам недостатньо розглянуто в педагогіці;

- необхідне технічне мислення і уважність. Дослідницька діяльність вимагає методичного підходу до роботи, виготовлення і реалізації, тому що загальнотехнічні дисципліни належать до інтегрованих наук, що об'єднують знання з фрізики, хімії, математики, інженерної і комп'ютерної графіки, конструкційних матеріалів, електротехніки, креслення, основ стандартизації, метрології та якості продукції, основ екології, безпеки життєдіяльності, охорони праці, економіки, організації і планування виробництва тощо.

\section{V Висновки}

Вивчення загальнотехнічних дисциплін в умовах інформаційно-освітнього середовища за допомогою інтерактивних аудіовізуальних засобів розширює можливості якісної підготовки здобувачів вищої освіти. Інтеграція навчання із використанням мобільно-планшетних засобів продовжує свій прискорений шлях росту. Для підготовки майбутніх фахівців доцільно формувати сучасні електронні інтерактивні посібники по дисциплінам для вивчення кожної дисципліни в умовах інформаційноосвітнього середовища. Такі посібники $€$ допомогою в опануванні як теоретичного матеріалу, так $\mathrm{i}$ навігацією по курсу, де представлені інтерактивні електронні навчальні інструменти для виконання завдань в умовах інформаційно-освітнього середовища. Такі завдання здобувачі вищої освіти виконують прямо в аудиторії за допомогою гаджетів або персональних комп'ютерів. Підсумкова оцінка формується з балів, отриманих в аудиторії та рейтингу здобувачів вищої освіти під час навчання в умовах інформаційно-освітнього середовища. Окреслений підхід здатний допомогти в якісному опануванні навчального контенту за обраним фахом. 


\section{Бібліографічні посилання}

[1] Трухин А. В. Виды виртуальных компьютерных лабораторий / Информационные технологии в высшем образовании. K, 2005. C. $58-67$.

[2] Белов В. В.,Образцов И. В., Иванов В.К., Коноплев Е. Н. Компьютерная реализация решения научно-технических и образовательных задач. Тверь: ТвГТУ, 2015. 108 с.

[3] Биков В. Ю. Сучасні завдання інформатизації освіти. Інформаційні технології і засоби навчання. 2010; 1(15). URL: http://journal.iitta.gov.ua/index.php/ittt (дата звернення 04.03.2019).

[4] Рамський Ю. С. Про роль математики і деякі тенденції розвитку математичної освіти в інформаційному суспільстві. Науковий часопис НПУ імені М. П. Драгоманова. Серія № 2: Комп'ютерно-орієнтовані системи навчання. 2008; № 6 (13): С. 12-16.

[5] Семеріков С. О. Теоретико-методичні основи фундаменталізації навчання інформатичних дисциплін у вищих навчальних закладах [дисертація]. Київ: Національний педагогічний ун-т ім. М. П. Драгоманова; 2009. 536 с.

[6] Триус Ю. В. "Комп'ютерно-орієнтовані методичні системи навчання математичних дисциплін у вищих навчальних закладах" [дисертація]. Черкаси: Черкаський нац. ун-т ім. Б. Хмельницького; 2005. 649 с. ISSN: $2076-8184$. Інформаційні технології і засоби навчання, 2018, Том 67, №5. 183

[7] Клочко В.ІІ, Бондаренко 3. В. Деякі аспекти методики застосування нових інформаційних технологій під час вивчення теми «Диференціальні рівняння» у вищому технічному навчальному закладі. Науковий часопис НПУ імені М. П. Драгоманова. Серія №2: Комп'ютерно-орієнтовані системи навчання. 2004; № 1(8): С.92-98.

[8] Співаковський О. В. Теорія й практика використання інформаційних технологій у процесі підготовки студентів математичних спеціальностей. Херсон : Айлант; 2003. 229 с.

[9] Вакалюк Т. А. Модель хмаро орієнтованої системи підтримки навчання бакалаврів інформатики. Інформаційні технології і засоби навчання. 2016; 6(56): C. 64-76. URL: http://journal.iitta.gov.ua/index.php/itlt/article/view/1415/1098 (дата звернення 04.03.2019).

[10] Биков В., Гуржій А., Шишкіна М. Концептуальні засади формування і розвитку хмаро орієнтованого навчальнонаукового середовища закладу вищої педагогічної освіти. Сучасні інформаційні технології та інноваційні методики навчання в підготовці фахівців: методологія, теорія, досвід, проблеми, 2018, № 50, С.20-25.

[11] Модернізація технології навчання в умовах реформи університетської освіти : колективна монографрія / за заг. ред. О.М. Самойленко, І.В. Бацуровської. Херсон : ОЛДІ-ПЛЮС, 2018. 456 с.

[12] Глазунова, "Методологічні засади створення та використання електронних навчальних ресурсів в системі вищої освіти", Інформаційні технології в економіці та природокористуванні, 2018, № 2, С. 45-55.

[13] Morze N., Buinytska O., Kuzminska O., Glazunova O., Protsenko G., Vorotnykova I. E-learning Managers Training at Universities: Projection, Design and Efficiency Indicators / ICT in Education, Research and Industrial Applications: Integration, Harmonization and Knowledge, 2017, vol. 62, no. 6, pp. 98-113

[14] Morze N., Smyrnova-Trybulska E., Glazunova O. Design of a University Learning Environment for SMART Education / Smart Technology Applications in Business Environments, 2107, USA: IGI Global, pp. 221-248.

[15] Авраменко О. Б. Загальнотехнічні дисципліни як освітня модель інтеграції науки, техніки і технології / Педагогічна освіта: теорія і практика. 2013. Вип. 13. С. 209-213. URL: http://nbuv.gov.ua/UJRN/znppo_2013_13_42 (дата звернення 04.03.2019).

[16] What Is The definition of Mobile Learning (M-learning)? URL: https://www.easy-Ims.com/knowledge-center/lms-knowledgecenter/mobile-learning/item10388 (дата звернення 04.03.2019).

[17] Asha Pandey. 10 Mobile Learning Trends For 2018. April 17, 2018. URL: https://elearningindustry.com/mobile-learningtrends-2018 (дата звернення 04.03.2019).

[18] 12 Principles Of Mobile Learning. URL: https://www.teachthought.com/learning/12-principles-of-mobile-learning/ (дата звернення 04.03.2019).

[19] Bogacgov Yu.M., Ukhan P. S., Yutsevych I.S. Competency analysis in the system of computer modeling of educational tasks URL: https://journal.iitta.gov.ua/index.php/itt/article/view/2631/1450 (дата звернення 04.03.2019).

[20] Шевчук П. Г. Організація дослідницької роботи учнів засобами хмарних сервісів Office 365. URL: nhttps://journal.iitta.gov.ua/index.php/ittl/article/view/2468/1445 (дата звернення 04.03.2019).

[21] Ясенко Я. В. Мультимедійний творчий проект як форма самостійної роботи студентів та чинник їх професійної соціалізації / Інформаційні технології і засоби навчання, 2019, Том 69, №1. URL: https://journal.iitta.gov.ua/index.php/ittl/article/view/2435/1444 (дата звернення 04.03.2019).

[22] Глинський Я. М., Ряжська В.А.Електронний освітній відеоресурс як темотвірний засіб навчання у курсі вищої математики / Інформаційні технології і засоби навчання, 2018, Том 68, №6, С. 64-76.

[23] Махомета Т. М., Вакалюк Т. А., Тягай І. М. Інформаційно-комунікаційні технології навчання аналітичної геометрії та лінійної алгебри майбутніх учителів фрізики й інформатики / Інформаційні технології і засоби навчання. 2018. №5 (67), C. 173-186.

[24] Glowacki J., Kriukowa Ye., Avshenjuk N. Gamification in higher education: experience of Poland and Ukraine / Advanced Education Issue 10, 2018. URL: http://ae.fl.kpi.ua/article/view/151143/152042 (дата звернення 04.03.2019).

[25] Mikhnenko G., Absaliamova Ye. The formation of intellectual mobility of engineering students through integration of foreign language education and professional training / Advanced Education, 2018, Issue 9, 33-38. URL: http://ae.fl.kpi.ua/article/view/121057/133429 (дата звернення 04.03.2019). 
[26] Алєксєєв О. М., Коротун М. М., Трєбухов Д. В. Використання анімації як засобу підвищення мотивації навчання студентів інженерних спеціальностей / Інформаційні технології і засоби навчання, 2018, Toм 65, No3. URL: https://journal.iitta.gov.ua/index.php/ittl/article/view/1985/1343 (дата звернення 04.03.2019).

[27] Величко С. П., Шульга С. В. Комп'ютерно орієнтовані засоби підтримки самостійної діяльності студентів у навчання квантової фрізики / Інформаційні технології і засоби навчання, 2018, Том 65, No3. URL: https://journal.iitta.gov.ua/index.php/itt/article/view/2225/1354 (дата звернення 04.03.2019).

[28] Курок В. П. Цілісна система загально-технічної підготовки вчителів трудового та професійного навчання: Авторефр. дис...канд. пед. наук: 130001 / Київ пед. ін-т, Київ, 1993. 24 с.

\section{References}

[1] Trukhyn, A. V. (2005). Vydi vyrtualnikh kompiuternikh laboratoryi / Ynformatsyonnie tekhnolohyy v visshem obrazovanyy. Kyiv, $58-67$.

[2] Belov, V. V., Obraztsov, Y. V., Yvanov, V. K., Konoplev, E. N. (2015). Kompiuternaia realyzatsyia reshenyia nauchnotekhnycheskykh y obrazovatelnikh zadach. TvHTU, Tver, Russia, 108. [in Russian]

[3] Bykov, V. Yu. (2010). Suchasni zavdannia informatyzatsii osvity. Informatsiini tekhnolohii i zasoby navchannia.; 1(15). URL: http://journal.iitta.gov.ua/index.php/itlt (accessed 04.03.2019). [in Ukrainian]

[4] Ramskyi, Yu. S. (2008). Pro rol matematyky i deiaki tendentsii rozvytku matematychnoi osvity v informatsiinomu suspilstvi. Naukovyi chasopys NPU imeni M. P. Drahomanova. Seriia № 2: Kompiuterno-oriientovani systemy navchannia.; № 6 (13): C. 12-16. [in Ukrainian]

[5] Semerikov, S. O. (2009). Teoretyko-metodychni osnovy fundamentalizatsii navchannia informatychnykh dystsyplin u vyshchykh navchalnykh zakladakh [dysertatsiia]. Natsionalnyi pedahohichnyi un-t im. M. P. Drahomanova, Kyiv, 536. [in Ukrainian]

[6] Tryus, Yu. V. (2018). "Kompiuterno-oriientovani metodychni systemy navchannia matematychnykh dystsyplin u vyshchykh navchalnykh zakladakh" [dysertatsiia]. Cherkasy: Cherkaskyi nats. un-t im. B. Khmelnytskoho; 2005. 649 s. ISSN: 20768184. Informatsiini tekhnolohii i zasoby navchannia, Tom 67, №5. 183. [in Ukrainian]

[7] Klochko, V. I., Bondarenko, Z. V. (2004). Deiaki aspekty metodyky zastosuvannia novykh informatsiinykh tekhnolohii pid chas vyvchennia temy «Dyferentsialni rivniannia» u vyshchomu tekhnichnomu navchalnomu zakladi. Naukovyi chasopys NPU imeni M. P. Drahomanova. Seriia №2: Kompiuterno-oriientovani systemy navchannia; № 1(8): C. 92-98. [in Ukrainian]

[8] Spivakovskyi, O. V. (2003). Teoriia y praktyka vykorystannia informatsiinykh tekhnolohii u protsesi pidhotovky studentiv matematychnykh spetsialnostei. Ailant, Kherson, 229. [in Ukrainian]

[9] Vakaliuk, T. A. (2016). Model khmaro oriientovanoi systemy pidtrymky navchannia bakalavriv informatyky. Informatsiini tekhnolohii i zasoby navchannia. 6(56), 64-76. URL: http://journal.iitta.gov.ua/index.php/itt/article/view/1415/1098 (accessed 04.03.2019). [in Ukrainian]

[10] Bykov, V., Hurzhii, A., Shyshkina, M. (2018). Kontseptualni zasady formuvannia i rozvytku khmaro oriientovanoho navchalnonaukovoho seredovyshcha zakladu vyshchoi pedahohichnoi osvity. Suchasni informatsiini tekhnolohii ta innovatsiini metodyky navchannia v pidhotovtsi fakhivtsiv: metodolohiia, teoriia, dosvid, problemy, № 50, 20-25. [in Ukrainian]

[11] Samoilenko, I. V., Batsurovskoi, O. M. (Ed.) (2018). Modernizatsiia tekhnolohii navchannia v umovakh reformy universytetskoi osvity : kolektyvna monohrafiia. OLDI-PLluS, Kherson, 456. [in Ukrainian]

[12] Hlazunova, (2018). "Metodolohichni zasady stvorennia ta vykorystannia elektronnykh navchalnykh resursiv $v$ systemi vyshchoi osvity", Informatsiini tekhnolohii v ekonomitsi ta pryrodokorystuvanni, № 2, 45-55. [in Ukrainian]

[13] Morze, N., Buinytska, O., Kuzminska, O., Glazunova, O., Protsenko, G., Vorotnykova, I. (2017). E-learning Managers Training at Universities: Projection, Design and Efficiency Indicators / ICT in Education, Research and Industrial Applications: Integration, Harmonization and Knowledge, vol. 62, no. 6, 98-113.

[14] Morze, N., Smyrnova-Trybulska, E., Glazunova, O. Design of a University Learning Environment for SMART Education. Smart Technology Applications in Business Environments, 2107, USA: IGI Global, 221-248.

[15] Avramenko, O. B. (2013). Zahalnotekhnichni dystsypliny yak osvitnia model intehratsii nauky, tekhniky i tekhnolohii $/$ Pedahohichna osvita: teoriia i praktyka. Vyp. 13. S. 209-213. URL: http://nbuv.gov.ua/UJRN/znppo_2013_13_42 (accessed 04.03.2019). [in Ukrainian]

[16] What Is The definition of Mobile Learning (M-learning)? URL: https://www.easy-Ims.com/knowledge-center/lms-knowledgecenter/mobile-learning/item10388 (accessed 04.03.2019).

[17] Asha Pandey. 10 Mobile Learning Trends For 2018. April 17, 2018. URL: https://elearningindustry.com/mobile-learningtrends-2018 (accessed 04.03.2019).

[18] 12 Principles Of Mobile Learning. URL: https://www.teachthought.com/learning/12-principles-of-mobile-learning/ (accessed 04.03.2019).

[19] Bogacgov, Yu. M., Ukhan, P. S., Yutsevych, I. S. Competency analysis in the system of computer modeling of educational tasks. URL: https://journal.iitta.gov.ua/index.php/itt/article/view/2631/1450 (accessed 04.03.2019).

[20] Shevchuk, P. H. Orhanizatsiia doslidnytskoi roboty uchniv zasobamy khmarnykh servisiv Office 365 . URL: nhttps://journal.iitta.gov.ua/index.php/itt/article/view/2468/1445 (accessed 04.03.2019). [in Ukrainian]

[21] Yasenko, Ya. V. (2019). Multymediinyi tvorchyi proekt yak forma samostiinoi roboty studentiv ta chynnyk yikh profesiinoi sotsializatsii / Informatsiini tekhnolohii i zasoby navchannia, Tom 69, №1. URL: https://journal.iitta.gov.ua/index.php/itt/article/view/2435/1444 (accessed 04.03.2019). [in Ukrainian] 
[22] Hlynskyi, Ya. M., Riazhska, V. A. (2018). Elektronnyi osvitnii videoresurs yak temotvirnyi zasib navchannia u kursi vyshchoi matematyky / Informatsiini tekhnolohii i zasoby navchannia, Tom 68, №6, 64-76. [in Ukrainian]

[23] Makhometa, T. M., Vakaliuk, T. A., Tiahai, I. M. (2018). Informatsiino-komunikatsiini tekhnolohii navchannia analitychnoi heometrii ta liniinoi alhebry maibutnikh uchyteliv fizyky y informatyky / Informatsiini tekhnolohii i zasoby navchannia. №5 (67), 173-186. [in Ukrainian]

[24] Glowacki, J., Kriukowa, Ye., Avshenjuk, N. (2018). Gamification in higher education: experience of Poland and Ukraine. Advanced Education Issue 10. URL: http://ae.fl.kpi.ua/article/view/151143/152042 (accessed 04.03.2019).

[25] Mikhnenko, G., Absaliamova, Ye. (2018). The formation of intellectual mobility of engineering students through integration of foreign language education and professional training. Advanced Education, Issue 9, 33-38. URL: http://ae.fl.kpi.ua/article/view/121057/133429 (accessed 04.03.2019).

[26] Alieksieiev, O. M., Korotun, M. M., Triebukhov, D. V. (2018). Vykorystannia animatsii yak zasobu pidvyshchennia motyvatsii navchannia studentiv inzhenernykh spetsialnostei. Informatsiini tekhnolohii i zasoby navchannia, Tom 65, No3. URL: https://journal.iitta.gov.ua/index.php/ittl/article/view/1985/1343 (accessed 04.03.2019). [in Ukrainian]

[27] Velychko, S. P., Shulha, S. V. (2018). Kompiuterno oriientovani zasoby pidtrymky samostiinoi diialnosti studentiv u navchannia kvantovoi fizyky. Informatsiini tekhnolohii i zasoby navchannia, Tom 65, No3. URL: https://journal.iitta.gov.ua/index.php/itt/article/view/2225/1354 (accessed 04.03.2019). [in Ukrainian]

[28] Kurok, V. P. (1993). Tsilisna systema zahalno-tekhnichnoi pidhotovky vchyteliv trudovoho ta profesiinoho navchannia: Avtoref. dys...kand. ped. nauk: 1300 01. Kyiv ped. in-t, Kyiv, 24. [in Ukrainian]

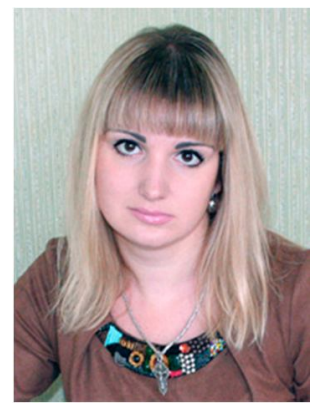

Доценко Наталія Андріївна.

Кандидат технічних наук, доцент, доцент кафедри загально технічних дисциплін,

Миколаївський національний аграрний університет,

вул. Георгія Гонгадзе, 9, м. Миколаїв, Україна, 54020.

Тел. 0951748474. dotsenkona@outlook.com

\section{Dotsenko Nataliia Andriivna.}

Ph.D., Associate Professor, Associate Professor of General Technical Disciplines Department Mykolayiv National Agrarian University,

vul. Heorhiia Honhadze, 9, m. Mykolaiv, Ukraina, 54020.

0951748474. dotsenkona@outlook.com

ORCID: 0000-0003-1050-8193
Researcher ID: C-5232-2017
Scopus ID: 57192819331

\section{Citation (APA):}

Dotsenko, N. (2019). Study of general technical disciplines via interactive audiovisual tools in conditions of informational and educational environment. Engineering and Educational Technologies, 7 (2), 137-148. doi: https://doi.org/10.30929/23079770.2019.07.02.14

\section{Цитування (ДСТУ 8302:2015):}

Доценко Н. А. Вивчення загальнотехнічних дисциплін в умовах інфоормаційно-освітнього середовища за допомогою інтерактивних аудіовізуальних засобів / Інженерні та освітні технологї. 2019. Т. 7. № 2. С. 137-148. doi: https://doi.org/10.30929/2307-9770.2019.07.02.14

Обсяг статті: сторінок - 12; умовних друк. аркушів - 1,738. 